\title{
Laboratory-scale simulations with hydrated lime and organic polymer to evaluate the effect of pre-chlorination on motile Ceratium hirundinella cells during conventional water treatment
}

\author{
H Ewerts $^{1,2}$, S Barnard ${ }^{1 *}$ and A Swanepoel ${ }^{2}$ \\ 'Unit for Environmental Sciences and Management, North-West University, Private Bag X6001, Potchefstroom, 2520, South Africa \\ 2Rand Water Analytical Services, PO Box 3526, Vereeniging, 1930, South Africa
}

\begin{abstract}
Algal genera such as Carteria, Chlamydomonas, Chlorogonium, Cryptomonas, Ceratium, Peridinium and Euglena are motile and may disrupt unit processes and cause water treatment problems. Algal species belonging to these motile algal genera are known to interfere with coagulation and flocculation unit processes which are the main processes for algal removal. These cells are well adapted, by means of their motile structures, morphological shapes and storage products, to remain in the supernatant (by swimming or floating) until it is carried over to sand filters, where cells may cause filter-clogging problems. When organic material is released from algal cells as a result of physical-chemical impacts on the cells, it may result in tasteand odour-related problems or the formation of harmful organic products such as trihalomethanes (THM). The aims of this study were to: (i) determine chlorine concentrations required to immobilise C. hirundinella cells; (ii) determine the removal efficiencies of pre-chlorination; (iii) investigate the integrity of $C$. hirundinella cells; and (iv) identify trihalomethanes that are formed. Source water samples enriched with C. hirundinella cells were exposed to a pre-determined chlorine concentration range $(0.05-0.45 \mathrm{mg} / \mathrm{L})$. This study found that the half-maximal inhibitory concentration $\left(\mathrm{IC}_{50}-\mathrm{values}\right)$ for chlorine $<0.20 \mathrm{mg} / \mathrm{L}$ is sufficient to render $C$. hirundinella cells immobile, while cells remain intact. Pre-chlorination did not have an impact on C. hirundinella removal when hydrated lime was used as a coagulant or coagulant aid. However, when organic polymer only was used as coagulant, removal efficiencies were improved by $20 \%$. Chlorine by-products were measured, but posed no specific health risks to drinking water consumers due to the low concentration levels measured. Algal removal challenges that occur in water treatment plants when dosing organic polymers can be resolved by implementation of effective pre-chlorination strategies.
\end{abstract}

Keywords: algae, coagulation, dinoflagellate, pre-treatment, trihalomethanes (THM)

\section{INTRODUCTION}

Ceratium hirundinella (C. hirundinella) is a well-known freshwater dinoflagellate. However, it has only been found to occur in extreme bloom-forming proportions in South Africa since 1999 (Van Ginkel et al., 2001a). C. hirundinella cells in source water treated for the production of drinking water have become a concerning issue to water treatment utilities, due to the fact that these cells may cause water purification related problems even at relatively low concentrations (Swanepoel et al., 2008a; Ewerts et al., 2013). The financial and operational impacts of C. hirundinella cells on the drinking water treatment industry are high, as this algal species is responsible for bad tastes and odours as well as clogging of sand filters (Van Ginkel et al., 2007). According to Pieterse et al. (2000) phytoplankton cells such as, C. hirundinella which contain flagella have the ability to: (i) interfere with conventional coagulation and flocculation by disrupting flocs and (ii) penetrate into the treated water. Studies undertaken by Ewerts et al. (2013) and Ewerts et al. (2014) support that this species is a problem-causing alga in conventional water treatment plants, and is responsible for floc disruption, filter clogging, increasing chlorine demand, taste and fishy-odour problems. Water treatment related problems caused by $C$. hirundinella cells can thus be ascribed to the fact that the dinoflagellate cells are large and highly motile, giving

\footnotetext{
* To whom all correspondence should be addressed.

๔ +27 (18) 299-2508; e-mail: sandra.barnard@nwu.ac.za

Received: 30 June 2015; accepted in revised form 10 March 2016
}

cells the advantage to migrate through the water column better than other algae (Gligora et al., 2003).

A chlorophyll breakthrough event into the treated water was observed at South Africa's largest conventional water treatment plant (SALCWTP) during the summer of 2006 (Swanepoel et al., 2008a). This was the result of high numbers of $C$. hirundinella cells entering the final treated water (Swanepoel et al., 2008a). It was evident that the biggest problems regarding the break-through were encountered at the sand filtration step, from where an average of $>2000$ cells/mL penetrated into the potable water (Swanepoel et al., 2008a). Although coagulation, flocculation and sedimentation removed some of the biomass, an increase in phytoplankton concentrations was observed after the sand filtration (Swanepoel et al., 2008a). Organic polymer was dosed as coagulant at flocculators supplying a part of the station and hydrated lime in combination with activated silica was dosed at all of the other flocculators (Swanepoel et al., 2008a). With the increase in C. hirundinella cell concentrations in the source water, an increase in algal breakthrough into the drinking water may occur when unit processes are not optimised. This is due to its unique characteristics that can impede its removal by means of coagulation, flocculation and subsequently sedimentation (Swanepoel et al., 2008a). Therefore, from September to April, when these highly motile dinoflagellate cells occur in source water in South Africa, water treatment plants are required to optimise unit processes and coagulant dosages in order to remove these cells. However, not all coagulant treatment options used by water treatment plants are able to aid in the effective removal 
of such motile algae. Pre-treatment strategies such as prechlorination can be applied to immobilise cells in order to assist coagulation and flocculation unit processes, which will subsequently improve removal efficiencies.

The implementation of pre-oxidation with various oxidants (e.g. chlorination, potassium permanganate, ozone) is widely applied for various pre-treatment purposes, such as control of algae and oxidising of organic material during water treatment (Van der Walt et al., 2009). Oxidants have biocidal properties; therefore, they can be used to control extensive aquatic growths such as phytoplankton (algae and cyanobacteria) and are also used as primary disinfectants (Van der Walt et al. 2009). Preoxidation chemicals, such as chlorine and ozone, are well-known to enhance phytoplankton removal during the production of drinking water (Knappe et al., 2004; Van der Walt et al., 2009; Ma et al., 2012). Various studies have shown improved phytoplankton removal efficiencies by conventional processes (e.g. coagulation, flocculation and sedimentation) as a result of pre-chlorination (Steynberg et al., 1994; Henderson et al., 2008 and Zamyadi et al., 2012). It was reported that chlorine inactivates microorganisms by crossing cell membranes and damaging the intracellular organelles (Venkobacher et al., 1977). In their study on the effects of pre-chlorination on cell integrity of Microcystis aeruginosa, Ma et al. (2012) found that, although chlorination led to a leaky membrane, no change in cell morphology was observed.

Organic material that originates from algae can leak out when the cell membrane is damaged and act as an important precursor for trihalomethanes (THM) (Abdullah et al., 2009; Van der Walt et al., 2009; Lui et al., 2011; Zamyadi et al., 2012). The formation of THM poses a potential health risk to drinking water consumers, since THM are mutagens, carcinogens and toxic (Abdullah et al., 2009; Hebert et al., 2010). In light of these risks associated with pre-chlorination, this study in particular focused on the use of effective chlorine concentrations required to immobilise at least $50 \%$ of the $C$. hirundinella cells, while cells remain intact, as well as monitoring the concentration of THM that formed as a result of pre-chlorination.

The pre-chlorination practice mentioned can be applied to immobilise $C$. hirundinella cells in order to assist coagulation and subsequently reduce the financial and operational impact on the water treatment facility. Therefore, the aims of this study were to: (i) evaluate chlorine concentrations required to immobilise $C$. hirundinella cells prior to coagulation, (ii) determine the removal efficiencies of pre-chlorination in combination with different coagulants, (iii) investigate the integrity of C. hirundinella cells, and (iv) identify the formation of chlorine byproducts.

\section{MATERIALS AND METHODS}

\section{Water samples: collection and preparation}

Source water from Benoni Lake, South Africa, containing relatively high $C$. hirundinella concentrations (ranging between 1000 and 4000 cells $/ \mathrm{mL}$ ) was collected during 4 sampling occasions (November-December 2011). During periods of low C. hirundinella concentrations present in the source water, cells were concentrated using a $50 \mu \mathrm{m}$ phytoplankton net to concentrate cells to $\geq 500$ cells $/ \mathrm{mL}$. No adverse effects on the morphology of $C$. hirundinella cells were noticed due to this concentration step. All water samples were collected in prewashed plastic containers and stored under laboratory conditions $\left( \pm 22^{\circ} \mathrm{C}\right)$.

\section{Determination of pre-chlorination concentrations using dose response fittings (half maximal inhibitory concentrations $I C_{50}$ ) and cell integrity (damage to cells)}

\section{Chlorine dosages}

The pre-chlorination method used for this study was adapted from an in-house method (used at analytical laboratories of SALCWTP) that is used to determine the acute toxicity of chlorine to Daphnia pulex (Bungu, 2009). Chlorine measurement procedures were adapted from standard methods as described by APHA, (2013). Chlorine concentrations were dosed into jar beakers (containing experimental water or filtered source water) with glassware and equipment (e.g., pipettes and syringes) that were chlorine saturated (no chlorine demand). This was achieved by soaking the glassware in $4 \mathrm{mg} / \mathrm{L}$ chlorine (prepared with deionised water) for $24 \mathrm{~h}$ before use. After $24 \mathrm{~h}$ the glassware was rinsed thoroughly with distilled water and dried.

Chlorine solutions were prepared to range from $0.05 \mathrm{mg} / \mathrm{L}$ up to $0.45 \mathrm{mg} / \mathrm{L}$ (with equal increments). This dosage range were used to conduct chlorine exposure experiments, since most of the cells collected during the early stages of the C. hirundinella bloom lost their integrity (cell lysis occurred) at $>0.45 \mathrm{mg} / \mathrm{L}$. Chlorine stock solutions were prepared from sodium hypochlorite, reagent grade, available chlorine $10-13 \%$ (Sigma-Aldrich). Chlorine measurements were performed using the HACH Pocket Colorimeter II Analysis System, using the diethyl-p-phenylene-diemine (DPD) tests, which can measure chlorine concentrations within the following ranges: 0.02 to $2.00 \mathrm{mg} / \mathrm{L} \mathrm{Cl}_{2}$ and 0.1 to $8.0 \mathrm{mg} / \mathrm{L} \mathrm{Cl}_{2}$. The typical pre-chlorination dosages (about $2-4 \mathrm{mg} / \mathrm{L} \mathrm{Cl}_{2}$ or $4-6 \mathrm{mg} / \mathrm{L} \mathrm{Cl}_{2}$ ) dosed for algal removal were not applicable to perform this method, but a new dosage range was determined as part of the study based on C. hirundinella cell immobilisation experiments. Therefore, no estimated detection limits for the pre-chlorination method used were known at the time of initiation of the experiment. Filtered source water enriched with a known concentration of C. hirundinella cells (target organisms) was exposed for approximately $5 \mathrm{~min}(T)$ to increasing concentrations $(C)$ ranging from $0.05 \mathrm{mg} / \mathrm{L}$ to $0.45 \mathrm{mg} / \mathrm{L}$ (with equal increments of 0.05). After 5 min exposure, an inverted light microscope was used to enumerate the number of immobilised C. hirundinella cells (used to draw the dose response graphs). All chlorine exposure experiments with different chlorine concentrations were conducted in triplicate.

\section{Water treatment simulations: pre-chlorination with and without coagulant treatments}

\section{Coagulant dosages}

All coagulant chemicals were collected from the treatment plant that was simulated during this study by means of jar stirring tests. The use of hydrated lime in combination with activated silica $\left(\mathrm{Ca}(\mathrm{OH})-\mathrm{SiO}_{2}\right)$ for destabilization and flocculation of suspended material is unique for the purification of Vaal Dam water in South Africa (Geldenhuys et al., 2000). South Africa's largest drinking water treatment plant selects coagulants and appropriate quantities based on a settling turbidity of $<5$ NTU, during jar stirring tests. The following coagulant stock solutions and dosage ranges were prepared to perform jar stirring tests: 
- $\mathrm{Ca}(\mathrm{OH})_{2}-\mathrm{SiO}_{2}: \mathrm{Ca}(\mathrm{OH})_{2}$ dosages ranged from 60 to $160 \mathrm{mg} / \mathrm{L}$ (in increments of 20). $\mathrm{A} \mathrm{SiO}_{2}$ dosage of $4 \mathrm{mg} / \mathrm{L}$ was dosed as a coagulant aid.

- $\mathrm{Ca}(\mathrm{OH})_{2}$-organic polymer: organic polymer (cationic high molecular weight) dosages ranged from 4 to $14 \mathrm{mg} / \mathrm{L}$ (in increments of 2). $\mathrm{A} \mathrm{Ca}(\mathrm{OH})_{2}$ dosage of $10 \mathrm{mg} / \mathrm{L}$ was added as a coagulant aid.

- Organic polymer: organic polymer dosages ranged from 4 to $14 \mathrm{mg} / \mathrm{L}$ with no coagulant aid (in increments of 2).

When dosing $\mathrm{Ca}(\mathrm{OH})_{2}-\mathrm{SiO}_{2}$ and $\mathrm{Ca}(\mathrm{OH})_{2}$-organic polymer, the $\mathrm{pH}$ values of source water may increase from around $\mathrm{pH}$ $8.00-8.79$ to $\geq \mathrm{pH} 11.5$ and $\geq \mathrm{pH} 9.5$, respectively, as recorded in the supernatant, while organic polymer alone may not be able to change the $\mathrm{pH}$ of the supernatant (Ewerts, 2015). During full-scale treatment, the $\mathrm{pH}$ of the supernatant is stabilised after sedimentation; however, this study only focuses on the improvement of flocculation and coagulation conditions as a result of pre-chlorination. The control of $\mathrm{pH}$ or removal of other impurities (from the supernatant) by subsequent unit processes such as chemical stabilisation and sand filtration (whereby supernatant is filtered) were not investigated during this study.

Pre-determined chlorine dosages (concentrations ranged between $0.05 \mathrm{mg} / \mathrm{L}$ and $0.45 \mathrm{mg} / \mathrm{L}$ ) to establish the half maximal inhibitory concentrations $\left(\mathrm{IC}_{50}\right.$ ) were dosed $5 \mathrm{~min}$ prior to flash mixing into $2000 \mathrm{~mL}$ experimental (filtered source) water samples containing 1360 cells/mL, 2583 cells $/ \mathrm{mL}$, 3746 cells $/ \mathrm{mL}$, and 1481 cells $/ \mathrm{mL}$, during sampling occasion$a$, occasion-b, occasion-c and occasion-d, respectively. The Phipps and Bird jar stirrer apparatus were used to conduct jar stirring tests. Different coagulant dosages were added with syringes and allowed to disperse uniformly at high-energy flash mixing conditions for another $30 \mathrm{~s}$. Three decreasing energy stages of $125 \mathrm{~s}^{-1}, 54 \mathrm{~s}^{-1}$ and $14 \mathrm{~s}^{-1}$ were applied for $8 \mathrm{~min}, 1.5 \mathrm{~min}$ and $1 \mathrm{~min}$ respectively. Stirring paddles were switched off to allow flocs to settle for $20 \mathrm{~min}$. Samples of the supernatants were collected to investigate the efficacy of coagulation, flocculation and sedimentation after dosing various coagulants.

\section{Ceratium hirundinella cell enumeration}

The sedimentation/centrifugation technique that was originally described by Lund et al. (1958) and adapted for Rand Water according to Swanepoel et al. (2008b), was used for identification and enumeration of $C$. hirundinella cells. The concentration (cells $/ \mathrm{mL}$ ) and physical integrity of $C$. hirundinella cells were determined and evaluated using an inverted light microscope.

\section{Total photosynthetic pigments (TPP)}

The presence of phytoplankton (algae and cyanobacteria) in water can be detected by a chlorophyll (chlorophyll- $a$, known as a photosynthetic pigment and other accessory pigments) analysis (Knappe et al., 2004; Swanepoel et al., 2008b).

Analytical laboratories analysing samples for SALCWTP have developed a more sensitive method for the detection of chlorophyll in lower concentrations. In this study, this method is referred to as the total photosynthetic pigment (TPP) analysis, which can be used to detect chlorophyll concentration when relatively low phytoplankton concentrations $(<40$ cells $/ \mathrm{mL})$ occur in the water, after different stages of water treatment as well as in the final treated water (Swanepoel et al., 2008b). After gravity sedimentation, the supernatant was analysed in terms of the content of TPP. Supernatant samples $(100 \mathrm{~mL})$ were filtered using membrane filters $(<0.45 \mu \mathrm{m})$. Membranes filters were boiled in $10 \mathrm{~mL}$ methanol to extract pigment into the methanol. Absorbance of the extract was measured at 650 and $750 \mathrm{~nm}$ using the Beckman Coulter (DU 65i) spectrophotometer (Swanepoel et al., 2008b).

\section{Total organic carbon (TOC), dissolved organic carbon (DOC) and trihalomethanes (THM)}

The content of organic matter was determined as total organic carbon (TOC) and dissolved organic carbon (DOC) using standard methods for examination of water and waste water samples (APHA 2013). TOC samples were collected headspace-free in $40 \mathrm{~mL}$ glass vials and preserved with $21 \%$ phosphoric acid and measurements performed (Phoenix and Fusion). Trihalomethanes (bromochloroform, bromoform, chloroform and dibromochloroform) were determined using a gas chromatograph linked to an electron capture detector (GCECD). The specific running conditions are listed in Table 1.

\section{Statistical analysis}

\section{T-Tests}

$T$-test analyses were performed to determine statistically significant differences between \%TPP removed by various coagulant dosages and \%TPP removed by coagulant dosages that were assisted by pre-chlorination (using Microsoft Office Excel 2007). The level of significance for all statistical analyses was set at $p$-values of 0.05 and the hypotheses were stated separately for each analysis with the hypothesised difference equal to zero.

\begin{tabular}{|l|l|l|l|}
\hline \multicolumn{4}{|c|}{ The Instrument configuration for GC-ECD parameters and running conditions } \\
\hline & Front inlet & $\begin{array}{l}\text { Capillary column (HP- } \\
\text { 1 methyl siloxane or } \\
\text { equivalent) }\end{array}$ & Front detector ( $\boldsymbol{\mu E C D )}$ \\
\hline Oven temperature: $40^{\circ} \mathrm{C}$ & Mode: Split & Maximum temperature: $300^{\circ} \mathrm{C}$ & Temperature: $315^{\circ} \mathrm{C}$ \\
\hline Run time: $10 \mathrm{~min}$ & Initial temperature: & Mode: Constant flow & Mode: Constant makeup flow \\
\hline & Pressure: $3.30 \mathrm{psi}(22.75 \mathrm{KPa})$ & Initial flow: $5.1 \mathrm{~mL} / \mathrm{min}$ & Makeup flow: $30.0 \mathrm{~mL} / \mathrm{min}$ \\
\hline & Split ratio: $10: 1$ & Average velocity: $36 \mathrm{~cm} / \mathrm{sec}$. & \\
\hline & Split flow: $51.1 \mathrm{~mL} / \mathrm{min}$ & & \\
\hline
\end{tabular}


To determine the chlorine concentration where $50 \%$ of the initial C. hirundinella cells are immobilised, described as the half maximal inhibitory concentration $\left(\mathrm{IC}_{50}\right)$, the dose response graphs (Hill slopes of CurveExpert Pro Version 2.0.3) were used. The concentration-response curves (showing a typical sigmoidal shape) in the Hill Slopes models were fitted to evaluate the $\mathrm{IC}_{50}$ (Henlory et al., 2013; Gadagkar and Call, 2015). In order to plot sigmoidal curves, data were normalised to percentage of the maximum response, and subtracting a baseline. The $y$-axis indicated the percentage cell immobilisation by the chlorine dosages on the $\mathrm{x}$-axis. The pre-chlorination dosages determined by dose response graphs were different (but remained below $1 \mathrm{mg} / \mathrm{L}$ ) due to different sampling occasions (changes in water quality) and cell integrity considerations.

\section{RESULTS}

The average value, minimum value, maximum value and standard deviation of water quality parameters measured for 10 sampling occasions $(n=10)$ in Table 2 represents a freshwater impoundment with a typical eutrophic status (based on nitrogen and phosphate values). The average turbidity of the water was relatively low at $7.32 \mathrm{NTU}$ with TDS values $\geq 100 \mathrm{mg} / \mathrm{L}$. Organic carbon (TOC) varied between $4.70 \mathrm{mg} / \mathrm{L}$ and $11.00 \mathrm{mg} / \mathrm{L}$ and should be considered as an important parameter to be evaluated during chlorine exposure experiments.

Effect of different chlorine concentrations on the motility and integrity of $C$. hirundinella cells

The effects of chlorine dosages on the motility and integrity of cells were observed microscopically. Figure la shows cells in the source water, while disruptions to cell integrity after chlorine exposure with dosages of $>0.20 \mathrm{mg} / \mathrm{L}$ are shown in Fig. 1c.
Figure 2 shows the dose response models for chlorine exposure experiments when dosing chlorine concentrations within the range of $0.05 \mathrm{mg} / \mathrm{L}$ to $0.45 \mathrm{mg} / \mathrm{L}$ (the range indicated in Fig. 2, varied between $0.05 \mathrm{mg} / \mathrm{L}$ and $0.25 \mathrm{mg} / \mathrm{L}$ ) to immobilise $50 \%$ of the initial C. hirundinella concentrations. During the different chlorine exposure experiments, the $\mathrm{IC}_{50}$ values and the impacts thereof on the integrity of cells were evaluated to determine the appropriate pre-chlorination dose (Table 3 ). Therefore, prechlorination values used during experiments may not necessarily correspond with the dose-response graphs due to cell integrity factors. The $\mathrm{IC}_{50}$ chlorine concentration values illustrated in the dose-response graphs a-b in Fig. 2 were below $0.20 \mathrm{mg} / \mathrm{L}$ with no specific correlations to the initial $C$. hirundinella concentrations. However, a poor sigmoidal graph (Hill slopes) illustration was observed for occasion-c which may be the result of cells becoming more sensitive to chlorine exposure; however, the prechlorination dose for immobilisation $(0.121 \mathrm{mg} / \mathrm{L})$ was similar to the dosage determined during occasion-a.

Table 3 lists the initial C. hirundinella concentrations in the source water used during these four chlorine exposure

\begin{tabular}{|l|c|c|c|c|}
\hline \multicolumn{5}{|c|}{ TABLE 3} \\
\begin{tabular}{|l} 
The initial C. hirundinella cell concentrations in \\
source water used to determine the pre-chlorination \\
concentrations during 4 chlorine exposure experiments.
\end{tabular} \\
\hline & 0ccasion-a & 0ccasion-b & Occasion-c & Occasion-d \\
\hline $\begin{array}{l}\text { Initial cell } \\
\text { concentrations } \\
\text { (cells/mL) }\end{array}$ & 1360 & 2583 & 3746 & 1481 \\
\hline $\begin{array}{l}\text { Pre-chlorination } \\
\text { concentration } \\
\text { (mg/L) }\end{array}$ & 0.121 & 0.186 & 0.121 & 0.106 \\
\hline
\end{tabular}

\section{TABLE 2}

The key parameters summarizing the quality of source water collected from Benoni Lake during the sampling period. According to the Department of Water and Sanitation's trophic status criteria, the chemical determinants listed below can be used to determine the trophic status of freshwater impoundments such as Benoni Lake (Van Ginkel et al., 2001b).

\begin{tabular}{|c|c|c|c|c|c|}
\hline & Units & Average $(n=10)$ & Minimum value & Maximum value & $\begin{array}{l}\text { Standard } \\
\text { deviation }\end{array}$ \\
\hline Nitrate $\left(\mathrm{NO}_{3}^{-}\right)$ & $\mathrm{mg} / \mathrm{L}$ & 0.95 & 0.00 & 8.60 & 2.69 \\
\hline Nitrite $\left(\mathrm{NO}_{2}^{-}\right)$ & $\mathrm{mg} / \mathrm{L}$ & 0.01 & 0.00 & 0.04 & 0.01 \\
\hline $\begin{array}{l}\text { Total Kjeldahl nitrogen } \\
\text { (TKN) }\end{array}$ & $\mathrm{mg} / \mathrm{L}$ & 2.41 & 1.20 & 5.90 & 1.32 \\
\hline Phosphorus (P) & $\mathrm{mg} / \mathrm{L}$ & 0.07 & 0.00 & 0.33 & 0.12 \\
\hline Total Phosphate (TP) & $\mathrm{mg} / \mathrm{L}$ & 0.01 & 0.00 & 0.09 & 0.03 \\
\hline $\begin{array}{l}\text { Chemical oxygen demand } \\
\text { (COD) }\end{array}$ & $\mathrm{mg} / \mathrm{L}$ & 22.00 & 16.00 & 33.00 & 4.90 \\
\hline Hardness as $\mathrm{CaCO}_{3}$ & $\mathrm{mg} / \mathrm{L}$ & 75.80 & 57.00 & 92.00 & 9.80 \\
\hline Total dissolved solids (TDS) & $\mathrm{mg} / \mathrm{L}$ & 148.50 & 100.00 & 200.00 & 31.63 \\
\hline Turbidity & NTU & 7.32 & 3.90 & 14.00 & 2.97 \\
\hline M-alkalinity as $\mathrm{CaCO}_{3}$ & $\mathrm{mg} / \mathrm{L}$ & 83.40 & 53.00 & 260.00 & 62.38 \\
\hline $\mathrm{pH}$ & & 6.59 & 6.24 & 6.99 & 0.24 \\
\hline Conductivity & $\mathrm{mS} / \mathrm{m}$ & 26.30 & 21.00 & 39.00 & 5.27 \\
\hline Total organic carbon (TOC) & $\mathrm{mg} / \mathrm{L}$ & 7.15 & 4.70 & 11.00 & 2.01 \\
\hline
\end{tabular}




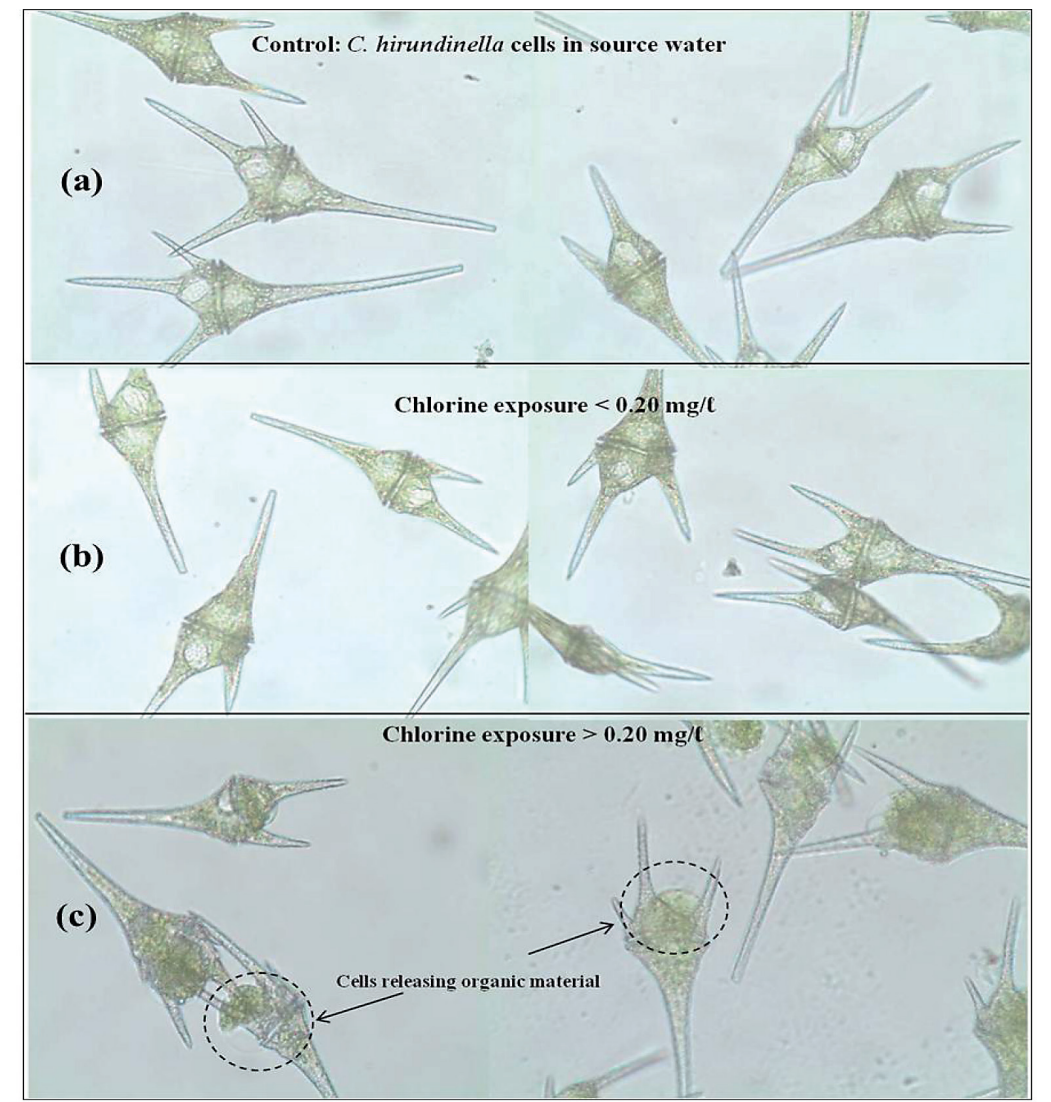

Figure 1

Light microscopy images of $\mathrm{C}$. hirundinella cells in source water (a) and the effects of chlorine concentrations after exposure to chlorine concentrations below $0.20 \mathrm{mg} / \mathrm{L}(\mathrm{b})$ and chlorine concentrations $\geq 0.20 \mathrm{mg} / \mathrm{L}$ (c).

(a)

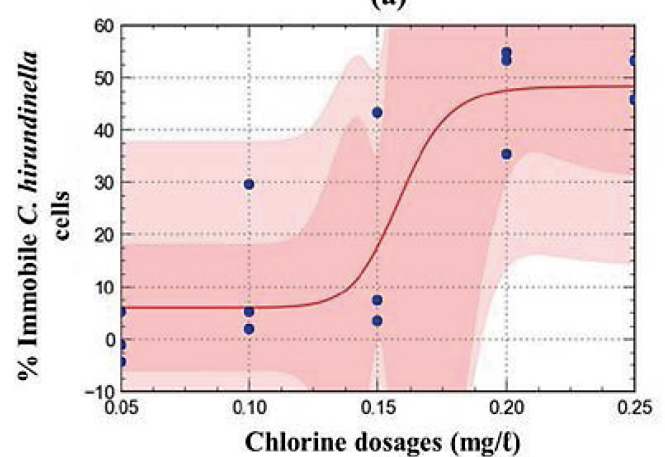

(c)

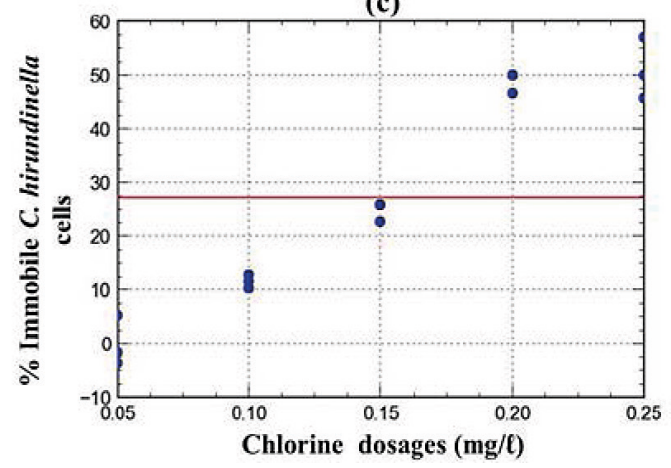

(b)

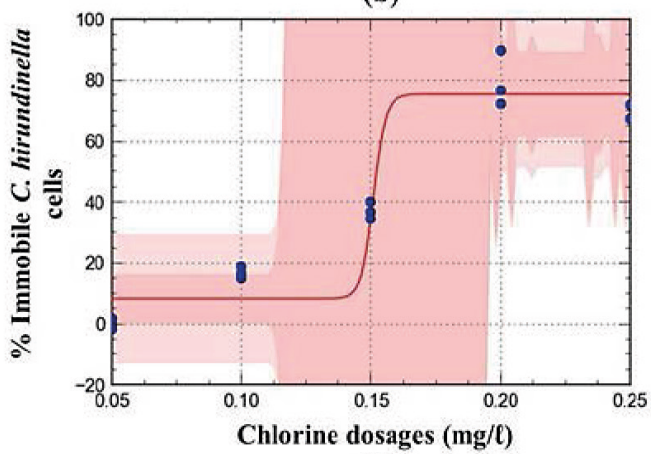

(d)

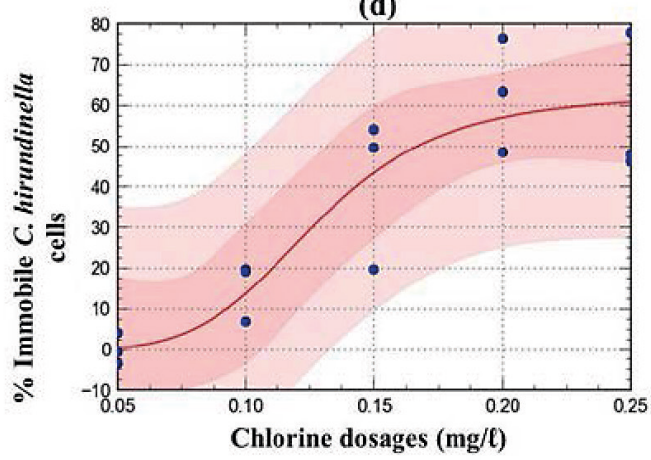

Figure 2

The dose-response models (Hill slopes) for 4 chlorine exposure experiments and the relationships between the percentages (\%) measured for immobilised C. hirundinella cells and increasing chlorine concentrations. 
experiments together with pre-chlorination concentrations. Although no specific correlations between the number of cells and pre-chlorination concentrations can be observed, the pre-chlorination concentrations used in this study were below $0.20 \mathrm{mg} / \mathrm{L}$.

\section{The effect of pre-chlorination on the percentage (\%) TPP removal during coagulation and flocculation}

Relatively low pre-chlorination concentrations (below $0.20 \mathrm{mg} / \mathrm{L})$ are indicated in Table $3(0.121 \mathrm{mg} / \mathrm{L}, 0.186 \mathrm{mg} / \mathrm{L}$, $0.121 \mathrm{mg} / \mathrm{L}$ and $0.106 \mathrm{mg} / \mathrm{L}$ ). These chlorine concentrations were dosed prior to coagulation, flocculation and sedimentation unit processes. Results obtained after sedimentation illustrate the removal efficiencies of $C$. hirundinella cells (indicated as \%TPP removal) when the following coagulants were dosed in combination with pre-determined chlorine concentrations: $\mathrm{Ca}(\mathrm{OH})_{2} \mathrm{SiO}_{2} ; \mathrm{Ca}(\mathrm{OH})_{2}$ organic polymer and organic polymer. These coagulant dosages were also dosed without pre-chlorination as a control to evaluate the removal efficiencies.

The effects of pre-chlorination (chlorine dose of $0.121 \mathrm{mg} / \mathrm{L}$ ) on \%TPP removal when dosing $\mathrm{Ca}(\mathrm{OH})_{2}-\mathrm{SiO}_{2}$ and
$\mathrm{Ca}(\mathrm{OH})_{2}$-organic polymer showed poor $C$. hirundinella cell removal as indicated by the \%TPP removal. The effect of prechlorination on C. hirundinella removal was better illustrated by the \%TPP removal when organic polymer alone was used as a coagulant option (Table 4 ). These results have indicated that organic polymer may not be the best coagulant option to remove $C$. hirundinella, but the effect of $C$. hirundinella immobilisation as a result of pre-chlorination is better shown when dosing organic polymer. On the other hand, when prechlorination was used prior to $\mathrm{Ca}(\mathrm{OH})_{2}$ treatment options, no improvement in the \%TPP was observed due to the effect of $\mathrm{pH}$ adjustments caused by $\mathrm{Ca}(\mathrm{OH})_{2}$ on $\mathrm{C}$. hirundinella cell removal. The effect of $\mathrm{pH}$ changes immobilised the cells; therefore, the effects of pre-chlorination on cell removal as a result of immobilisation could not be observed in the \%TPP removal. Due to these previous findings, organic polymer without a coagulant aid was dosed as the primary coagulant during experimental occasion-b; occasion-c and occasion- $d$ to illustrate the effect of pre-chlorination (Table 5). Results in Table 5 were obtained using the chlorine concentrations of $0.186 \mathrm{mg} / \mathrm{L}, 0.121 \mathrm{mg} / \mathrm{L}$ and $0.106 \mathrm{mg} / \mathrm{L}$ that were able to assist the lowest organic coagulant dosage of $4 \mathrm{mg} / \mathrm{L}$ to improve the percentage TPP removal

\section{TABLE 4}

The \%TPP removal by various coagulants compared to \%TPP removal achieved when the same coagulants were assisted by pre-chlorination. Pre-chlorination concentration of $0.121 \mathrm{mg} / \mathrm{L}$ as previously determined during occasion-a (Table 3).

\begin{tabular}{|c|c|c|c|c|c|c|c|c|}
\hline \multicolumn{3}{|c|}{$\begin{array}{c}\mathrm{Ca}(\mathrm{OH})_{2}-\mathrm{SiO}_{2} \\
\mathrm{Ca}(\mathrm{OH})_{2} \text { dosages }(60-160 \mathrm{mg} / \mathrm{L} \text { increments of } 20)\end{array}$} & \multicolumn{3}{|c|}{\begin{tabular}{|c|}
$\mathrm{Ca}(\mathrm{OH})_{2}$-organic polymer \\
Organic polymer dosages (4-14 mg/L increments of 2$)$
\end{tabular}} & \multicolumn{3}{|c|}{$\begin{array}{c}\text { Organic polymer } \\
\text { Dosages }(4-14 \mathrm{mg} / \mathrm{L} \text { increments of } 2)\end{array}$} \\
\hline $\begin{array}{c}\text { Control } \\
\text { \%TPP removal }\end{array}$ & $\begin{array}{c}\text { Pre-Cl } \\
\text { \%TPP removal }\end{array}$ & $\begin{array}{l}\text { Removal } \\
\text { success }\end{array}$ & $\begin{array}{c}\text { Control } \\
\text { \%TPP removal }\end{array}$ & $\begin{array}{c}\text { Pre- } \mathrm{Cl}_{2} \\
\text { \%TPP removal }\end{array}$ & $\begin{array}{l}\text { Removal } \\
\text { success }\end{array}$ & $\begin{array}{c}\text { Control } \\
\text { \%TPP removal }\end{array}$ & $\begin{array}{c}\text { Pre- } \mathrm{Cl}_{2} \\
\text { \%TPP removal }\end{array}$ & $\begin{array}{l}\text { Removal } \\
\text { success }\end{array}$ \\
\hline 58.90 & 60.27 & $\checkmark$ & 43.15 & 33.56 & $x$ & 28.08 & 38.36 & $\checkmark$ \\
\hline 74.66 & 63.01 & $x$ & 50.68 & 45.89 & $x$ & 30.14 & 34.25 & $\checkmark$ \\
\hline 93.15 & 86.99 & $x$ & 52.74 & 60.96 & $\checkmark$ & 34.93 & 43.15 & $\checkmark$ \\
\hline 96.44 & 95.00 & $x$ & 64.38 & 65.75 & $\checkmark$ & 50.00 & 55.48 & $\checkmark$ \\
\hline 97.74 & 96.37 & $x$ & 76.03 & 73.97 & $x$ & 60.27 & 65.07 & $\checkmark$ \\
\hline 98.29 & 97.67 & $x$ & 78.77 & 76.71 & $x$ & 61.64 & 68.49 & $\checkmark$ \\
\hline$p$-value & & 0.37 & $p$-value & & 0.44 & $p$-value & & 0.23 \\
\hline
\end{tabular}

Removal success: The effect of pre-chlorination on \%TPP removal is indicated with a tick $(\boldsymbol{V})$, while no improved \%TPP removal is indicated with a cross $(\boldsymbol{X})$. The 6 percentages in the table for \%TPP removal were obtained from 6 increasing coagulant dosages (with equal increments) for each treatment option.

TABLE 5

The \%TPP removal by organic polymer compared to \%TPP removal achieved when organic polymer were assisted by prechlorination (control). Organic polymer dosages (4-14 mg/L increments of 2). See occasion-b, occasion-c and occasion-d (Table 3).

\begin{tabular}{|c|c|c|c|c|c|c|c|c|}
\hline \multicolumn{3}{|c|}{$\begin{array}{l}\text { Occasion-b } \\
\text { (Pre-chlorination concentration } 0.186 \mathrm{mg} / \mathrm{L} \text { ) }\end{array}$} & \multicolumn{3}{|c|}{$\begin{array}{l}\text { Occasion-c } \\
\text { (Pre-chlorination concentration } 0.121 \mathrm{mg} / \mathrm{L} \text { ) }\end{array}$} & \multicolumn{3}{|c|}{$\begin{array}{l}\text { Occasion-d } \\
\text { (Pre-chlorination concentration } 0.106 \mathrm{mg} / \mathrm{L} \text { ) }\end{array}$} \\
\hline $\begin{array}{c}\text { Control } \\
\text { \%TPP removal }\end{array}$ & $\begin{array}{c}\text { Pre- } \mathrm{Cl}_{2} \\
\text { \%TPP removal }\end{array}$ & $\begin{array}{l}\text { Removal } \\
\text { success }\end{array}$ & $\begin{array}{l}\text { Control } \\
\text { \%TPP removal }\end{array}$ & $\begin{array}{c}\text { Pre- } \mathrm{Cl}_{2} \\
\text { \%TPP removal }\end{array}$ & $\begin{array}{c}\text { Removal } \\
\text { success }\end{array}$ & $\begin{array}{c}\text { Control } \\
\text { \%TPP removal }\end{array}$ & $\begin{array}{c}\text { Pre- } \mathrm{Cl}_{2} \\
\text { \%TPP removal }\end{array}$ & $\begin{array}{c}\text { Removal } \\
\text { success }\end{array}$ \\
\hline 32.31 & 41.54 & $\checkmark$ & 31.90 & 52.16 & $\checkmark$ & 29.82 & 31.58 & $\checkmark$ \\
\hline 36.92 & 44.62 & $\checkmark$ & 41.81 & 53.02 & $\checkmark$ & 31.58 & 40.35 & $\checkmark$ \\
\hline 35.38 & 49.23 & $\checkmark$ & 48.71 & 64.22 & $\checkmark$ & 35.09 & 43.86 & $\checkmark$ \\
\hline 49.23 & 63.08 & $\checkmark$ & 63.36 & 76.72 & $\checkmark$ & 49.12 & 57.89 & $\checkmark$ \\
\hline 53.85 & 67.69 & $\checkmark$ & 72.41 & 83.62 & $\checkmark$ & 59.65 & 66.67 & $\checkmark$ \\
\hline 49.23 & 69.23 & $\checkmark$ & 76.72 & 87.07 & $\checkmark$ & 29.82 & 31.58 & $\checkmark$ \\
\hline$p$-value & & 0.03 & $p$-value & & 0.09 & $p$-value & & 0.22 \\
\hline
\end{tabular}

Removal success: The effect of pre-chlorination on \%TPP removal is indicated with a tick $(\checkmark)$, while no improved \%TPP removal is indicated with cross $(\boldsymbol{X})$. The 6 percentages in the table for \%TPP removal were obtained from 6 increasing coagulant dosages (with equal increments) for each treatment option. 
TABLE 6

The minimum (min.) and maximum (max.) values for THM (bromodichloroform and chloroform) after chlorine exposure experiments and organic carbon (TOC and DOC) concentrations measured in samples collected during 4 sampling occasions (a-d).

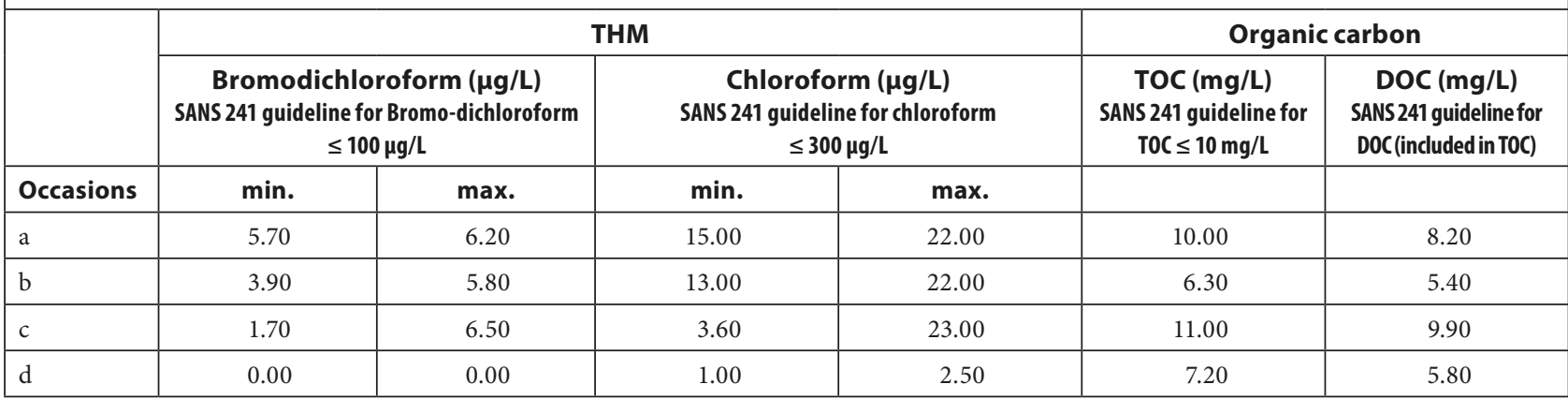

South African National Standards for drinking water (SANS 241)

by $9 \%, 20 \%$ and $2 \%$ respectively. The highest dosage $(14 \mathrm{mg} / \mathrm{L})$, on the other hand, improved the TPP removal percentages by $20 \%, 10 \%$ and $2 \%$, respectively.

\section{The formation of trihalomethanes (THM) during pre-chlorination}

Large algae, such as C. hirundinella cells, contribute to significant quantities of the total organic carbon (TOC) in source water (Table 2). When chlorine reacts with TOC in the source water, it results in the formation of harmful chlorine by-products known as trihalomethanes. TOC and DOC concentrations measured in source water during all sampling occasions varied from $6.3-11 \mathrm{mg} / \mathrm{L}$ and $5.4-9.9 \mathrm{mg} / \mathrm{L}$, respectively. The concentrations of organic carbon compounds measured during different sampling occasions of this study were relatively similar, while increased THM concentrations were measured as a result of increasing chlorine concentrations.

Four THM were present after chlorine exposure, namely; bromodichloroform, bromoform, chloroform and dibromochloroform. The THM consisted mostly of bromodichloroform and chloroform, since bromoform and dibromochloroform were below the detection limits of the method used in this study. The minimum $(\min )$ and maximum $(\max )$ values measured for bromodichloroform and chloroform is given in Table 6 . These values were obtained after dosing a chlorine range of 0.05 to $0.45 \mathrm{mg} / \mathrm{L}$.

\section{DISCUSSION}

Extreme blooms of C. hirundinella in South African impoundments have become more frequent since it was first observed in 1999 in the Hartbeespoort Dam (Van Ginkel et al., 2001a, Barnard et al., 2014). A breakthrough event observed at SALCWTP highlighted the problems that can be experienced during the production of potable water when blooms of C. hirundinella occur in source waters (Swanepoel et al., 2008). When such environmental changes (algal blooms) occur that have an impact on source water quality, a conventional water treatment plant should be able to optimise unit processes or have effective pre-treatment options to ensure good drinking water quality.

Water samples enriched with $C$. hirundinella cells were collected from a freshwater lake (Benoni Lake, South Africa) from early spring (September) until late autumn (March) months. During early spring months cells appeared highly motile with no damaged cells (as observed with light microscope after sampling), but become less active by means of motility towards the late autumn months, with a few damaged cells that will release organic material into the source water. Therefore, effective monitoring and optimisation strategies are required to assist water treatment plant managers and operators during events of C. hirundinella blooms, especially by treatment facilities where pre-chlorination is used to improve the removal of algae.

This study has shown that pre-chlorination can be used effectively, prior to water treatment, to assist coagulation and flocculation unit processes, specifically when organic polymers are used as principle coagulant chemical. However, when implementing pre-chlorination, the integrity of cells should be monitored to avoid cell lysis which may lead to taste and odour problems as well as an increase in TOC and DOC and the related formation of THM in the drinking water. Studies have shown that different algal genera differ in their resistance to cell damage caused by pre-oxidation treatments (Steynberg et al., 1994; Liao et al., 2015; Coral et al., 2013; Lin et al., 2009; Ma et al., 2012).

Most of these studies investigated the effects of pre-chlorination or pre-ozonation on the cell integrity of cyanobacteria, diatoms and green algae. The presence of $C$. hirundinella recorded during warmer months of spring (September to November), summer (December - February) and autumn (March) in various South African impoundments such as the Benoni Lake, highlighted the fact that very little is known about the effect of pre-chlorination on the cells as well as on the flocculation of dinoflagellates. Dinoflagellates maintain their position in the water column by swimming, which gives cells the ability to interfere with conventional coagulation and flocculation by disrupting flocs (Pieterse et al., 2000).

Unlike previous studies (Lin et al., 2009; Ma et al., 2012; Zamyadi et al., 2012), where algal or cyanobacterial cells were collected from culture media, the algal cells used during this study were collected from natural source water and resuspended in natural filtered source water to conduct chlorine exposure experiments. During this study the pre-chlorination dosages required to achieve $50 \%$ immobility of cells were much lower than previously recorded $(0.121 \mathrm{mg} / \mathrm{L}, 0.186 \mathrm{mg} / \mathrm{L}$, $0.121 \mathrm{mg} / \mathrm{L}$ and $0.106 \mathrm{mg} / \mathrm{L}$ respectively) (Steynberg et al., 1994; Zamyadi et al., 2012). According to Zamyadi et al. (2012), the industry dosages determined as $\mathrm{Cl}_{2}$ to DOC ratios are low $\left(<1.5 \mathrm{Cl}_{2}\right.$ : DOC). During this study ratios of between 0.012 and $0.03\left(\mathrm{Cl}_{2}: \mathrm{DOC}\right)$ were applied for the different sampling occasions. These results indicate that the relatively low chlorine dosage range $(<1 \mathrm{mg} / \mathrm{L})$ required for immobilisation purposes 
may reduce the treatment costs significantly. The effects of different pre-chlorination dosages on the integrity of cells were observed microscopically. Disruptions to cell integrity after chlorine exposure were observed with dosages 5 to 10 times lower $(0.20 \mathrm{mg} / \mathrm{L})$ than observed in other studies $(1-5 \mathrm{mg} / \mathrm{L})$ (Lin et al., 2009; Zamyadi et al., 2010; Zamyadi et al., 2012).

When considering pre-chlorination to immobilise algal cells such as C. hirundinella, the primary coagulant dosed during coagulation also plays a major role, since coagulant options containing $\mathrm{Ca}(\mathrm{OH})_{2}$ can also render motile cells immobile. $\mathrm{Ca}(\mathrm{OH})_{2}$ increases the $\mathrm{pH}$ levels of water, which have similar impacts as chlorine on flagellated organisms, such as C. hirundinella (Ferreira and Du Preez, 2012). Pre-chlorination implemented to assist $\mathrm{Ca}(\mathrm{OH})_{2}-\mathrm{SiO}_{2}$ and $\mathrm{Ca}(\mathrm{OH})_{2}$-organic polymer was not effective in enhancing the decrease of \%TPP removal. When dosing organic polymer only, no $\mathrm{pH}$ adjustments occurred and the treatment subsequently removed less $C$. hirundinella cells when compared to other coagulant options. This means that C. hirundinella cells can remain motile and disrupt the coagulation and flocculation processes. Table 5 confirmed the good removal efficiencies of $C$. hirundinella cells as a result of prechlorination when dosing organic polymer as the only coagulant. These results confirmed that continuous $C$. hirundinella cell removals can be achieved by conventional unit processes (coagulation, flocculation) when coupled to pre-chlorination. Steynberg et al. (1994) and Henderson et al. (2008) also stated that improvements in removal efficiencies of up to $95 \%$ can be expected when immobilisation assists coagulation and flocculation, depending on the chemical used.

Organic material excreted or released from algae, such as algal hydrophilic protein, is difficult to remove during coagulation and flocculation and may pose risks when penetrating the final disinfection stage of water treatment when chlorine is used as a disinfectant (Lui et al., 2011; Shen et al., 2011). It is wellknown that organic material arising from algae serves as precursor material for the formation of harmful chlorine by-products, such as THM, and may cause unpleasant tastes and odours in drinking water (Goslan et al., 2009; Zamyadi et al., 2012). The most commonly found THM (bromodichloroform, bromoform, chloroform and dibromochloroform) were identified during this study; however, only bromodichloroform and chloroform were measured above the method limit of detection. Lui et al. (2011) stated that algal hydrophilic protein has a high chloroform formation potential when dosing chlorine which could explain the fact that chloroform was the most abundant THM found.

The guidelines set for South African drinking water are similar to guidelines set by the WHO, as indicated by SANS 241:2015 (SANS 241: 2015, 2015). THM concentrations that are formed during pre-chlorination of this study are not an issue for concern, since concentrations were measured at levels of $<100 \mu \mathrm{g} / \mathrm{L}$. However, higher THM may form as a result of increased chlorine concentrations (e.g. chlorine overdose, or during higher dosages for disinfection after sand filtration). Therefore, water treatment plants that use pre-chlorination can reduce the THM entering the treatment plant by using an additional aeration step or allowing pre-chlorinated water to be exposed to ambient temperature in order to release THM into the atmosphere.

\section{CONCLUSIONS}

The integrity of $C$. hirundinella cells remains undisrupted when dosing the appropriate pre-chlorination dosage (e.g. $\mathrm{IC}_{50}$ ) as required for rendering cells immobile, which will subsequently result in effective flocculation when dosing organic polymer. These immobile cells are also much more sensitive to cell damage by oxidation when using pre-chlorination; therefore, light microscopy investigations should be used to monitor the integrity of cells. Pre-chlorination practices aimed at algal cell immobilisation can be implemented at a relatively low treatment cost when the DOC and TOC concentrations are relatively low. The low pre-chlorination dosages in combination with low carbon content (DOC and TOC) observed during this study are not a matter of concern for water quality, since the THM concentrations measured after pre-chlorination were lower than the SANS guideline values. However, careful consideration should be given by plant managers and process controllers when using elevated pre-chlorination dosages to treat source water characterised by high DOC and TOC concentrations.

When source water used for the production of drinking water is enriched with phytoplankton cells (algae and cyanobacteria), treatment options which include hydrated lime $\left(\mathrm{Ca}(\mathrm{OH})_{2}\right)$ may result in aggravation of water treatment problems such as tastes and odours. The elevated pH levels ( $\geq \mathrm{pH} 10)$ are sufficient to inactivate organisms such as algae and cyanobacteria. These water treatment plants should therefore avoid using additional treatment steps such as pre-chlorination. On the other hand, water treatment plants that dose organic polymer as the only coagulant may experience treatment problems associated with motile algae (e.g. flagellated algal genera such as Carteria, Chlamydomonas, Chlorogonium, Cryptomonas, Ceratium, Peridinium and Euglena). To resolve floc disruption, especially by flagellated algal genera, it is recommended to implement prechlorination (to render cells immobile) prior to coagulation and flocculation unit processes to ensure effective removal of algae by gravity sedimentation or dissolved air floatation.

\section{REFERENCES}

ABDULLAH MP, YEE IF, ATA S, ABDULLAH A, ISHAK B, and ABIDIN KNZ (2009) The Study of interrelationship between raw water quality parameters, chlorine demand and the formation of disinfection by-products. Phys. Chem. Earth 34 806-811. http:// dx.doi.org/10.1016/j.pce.2009.06.014

APHA (AMERICAN PUBLIC HEALTH ASSOCIATION) (2013) Standard Methods for the Examination of Water and Wastewater (22 ${ }^{\text {nd }}$ edn). APHA, Washington D.C.

BAEK SH, SHIMODE S, SHIN K, HAN M and KIKUCHI T (2009) Growth of dinoflagellates, Ceratium furca and Ceratium fusus in Sagami Bay, Japan: the role of vertical migration cell division. Harmful Algae 8 843-856. http://dx.doi.org/10.1016/j. hal.2009.04.001

BARNARD S, VAN GINKEL CE, COETZEE LZ and BOOYENS S (2014) Implementation of the rule based agent for Microcystis in Rietvlei Dam. WRC Report No. 1962/1/13. Water Research Commission, Pretoria.

BUNGU L (2009) Acute toxicity of chlorine to Daphnia pulex. Internal report produced by Scientific Services Division of Analytical Services, Hydrobiology Section, Rand Water, Vereeniging, South Africa.

CORAL LA, ZAMYADI A, BARBEAU B, BASSETTI FJ, LAPOLLI FR and PRÉVOST M (2013) Oxidation of Microcystis aeruginosa and Anabaena flos-aquae by ozone: Impacts on cell integrity and chlorination by-product formation. Water Res. 47 2983-2994. http:// dx.doi.org/10.1016/j.watres.2013.03.012

EWERTS H (2015) Laboratory-scale evaluation of different aspects related to Ceratium hirundinella removal during simulation of a conventional water treatment plant which includes sedimentation. PhD thesis, North-West University, Potchefstroom.

EWERTS H, BARNARD S, SWANEPOEL A, DU PREEZ HH and JANSE VAN VUUREN S (2014) Strategies of coagulant 
optimization to improve the removal of Ceratium hirundinella cells during conventional water purification. Water Sci. Technol. Water Supply 14 (5) 820-828. http://dx.doi.org/10.2166/ws.2014.038

EWERTS H, SWANEPOEL A and DU PREEZ HH (2013) Efficacy of conventional drinking water treatment processes in removing problem-causing phytoplankton and associated organic compounds. Water SA 39 (5) 739-750. http://dx.doi.org/10.4314/wsa.v39i5.19

FERREIRA L and DU PREEZ HH (2012) Investigation into the occurrence of aquatic invertebrates throughout drinking water purification plants. Water Sci. Technol. Water Supply 12 (2) 250-257. http:// dx.doi.org/10.2166/ws.2012.136

GADAGKAR SR and CALL GB (2015) Computational tools for fitting the Hill equation to dose-response curves. J. Pharmacol. Toxicol. Meth. 71 68-76. http://dx.doi.org/10.1016/j.vascn.2014.08.006

GELDENHUYS JC, GIARD E, HARMSE M, NEVELING K and POTGIETER M (2000) The use of ozonation in combination with lime and activated sodium silicate in water treatment. WRC Report No. 446/1/00. Water Research Commission, Pretoria.

GLIGORA M, PLENKOVIĆ-MORAJ A and TERNJEJ I (2003) Seasonal distribution and morphological changes of Ceratium hirundinella in two Mediterranean Shallow Lakes. Hydrobiologia 506-509 213-220. http://dx.doi. org/10.1023/B:HYDR.0000008607.07210.24

GOSLAN EH, KRASNER SW, BOWER N, ROCKS SA, HOLMES P, LEVY LS and PARSONS SA (2009) A comparison of disinfection by-products found in chlorinated and chloraminated drinking waters in Scotland. Water Res. 43 4698-4706. http://dx.doi. org/10.1016/j.watres.2009.07.029

HEBERT A, FORESTIER D, LENES D, BENANOU D, JACOB S, ARFI C, LAMBOLEZ L and LEVI Y (2010) Innovative method for prioritizing emerging disinfection by-products (DBPs) in drinking water on the basis of their potential impact on public health. Water Res. 44 3147-3165. http://dx.doi.org/10.1016/j.watres.2010.02.004

HENDERSON R, PARSONS SA and JEFFERSON B (2008) The Impact of algal properties and preoxidation on solid-liquid separation of algae. Water Res. 42 (8-9) 1827-1845. http://dx.doi.org/10.1016/j. watres.2007.11.039

HERLORY O, BONZOM J and GILBIN R (2013) Sensitivity evaluation of the green alga Chlamydomonas reinhardtii to uranium by pulse amplitude modulated (PAM) fluorometry. Aquat. Toxicol. 140-141 288-294. http://dx.doi.org/10.1016/j.aquatox.2013.06.007

KNAPPE DRU, BELK RC, BRILEY DS, GANDY SR, RASTOGI N, RIKE AH, GALSGOW H, HANNON E, FRAZIER WD, KOHL P and PUGSLEY S (2004) Algae detection and removal strategies for drinking water treatment plants. Report number 90971. AWWA Research Foundation, Denver. 466 pp.

LIAO X, LIU J, YANG M, MA H, YUAN B and HUANG C (2015) Evaluation of disinfection by-product formation potential (DBPFP) during chlorination of two algae species - blue-green Microcystis aeruginosa and diatom Cyclotella meneghiniana. Sci. Total Environ. 532 540-547. http://dx.doi.org/10.1016/j.scitotenv.2015.06.038

LIN TF, CHANG DW, LIEN SK, TSENG YS, CHIU YT and WANG YS (2009) Effect of chlorination on the cell integrity of two noxious cyanobacteria and their releases of odorants. J. Water Supply Res. Technol. 58 (8) 539-551. http://dx.doi.org/10.2166/aqua.2009.117

LUI YS, QIU JW, ZHANG YL, WONG MH and LIANG Y (2011) Algal-derived organic matter as precursors of disinfection by-products and mutagens upon chlorination. Water Res. 45 1454-1462. http://dx.doi.org/10.1016/j.watres.2010.11.007

LUND JWG, KIPLING C and LECREN ED (1958) The inverted microscope method of estimating algal numbers and the statistical basis of estimations by counting. Hydrobiologia 11 143-170. http:// dx.doi.org/10.1007/BF00007865
MA M, LIU R, LIU H, QU J and JEFFERSON W (2012) Effects and mechanisms of pre-chlorination on Microcystis aeruginosa removal by alum coagulation: significance of the released intracellular organic matter. Sep. Purif. Technol. 86 19-25. http://dx.doi. org/10.1016/j.seppur.2011.10.015

PIETERSE AJH, BASSON ND, CLOOT A, MIENIE LJ, TRAUT, DF and VISSER R (2000) The occurrence, distribution and removal of algal species and related substances in a full-scale water purification plant. WRC Report No. 567/1/00. Water Research Commission, Pretoria.

SHEN Q, ZHU J, CHENG L, ZHANG J, ZHANG Z and XU X (2011) Enhanced Algae Removal by Drinking Water Treatment of Chlorination Coupled with Coagulation. Desalination 271236 240. http://dx.doi.org/10.1016/j.desal.2010.12.039

SOUTH AFRICAN NATIONAL STANDARDS 241:2015 (SANS 214:2015) (2015) Drinking Water. Microbiological, Physical, Aesthetic and Chemical Determinants. South African Bureau of Standards, Pretoria.

STEYNBERG MC, GELDENHUYS JC, GUCLIELMI MM, GROBLER $S$ and MAREE B (1994) The influence of water quality on the efficiency of chlorine dioxide as pre-oxidant and algicide in the production of potable water. WRC Report No. 281/1/94. Water Research Commission, Pretoria.

SWANEPOEL A, DU PREEZ HH, DUSRATH I and RAJELE M (2008a) Ceratium hirundinella reveals algal penetration into the potable water at Rand Water. Proc. Water Institute of Southern Africa Biennial Conference (WISA 2008), Sun City, 18-22 May 2008, South Africa.

SWANEPOEL A, DU PREEZ HH, SCHOEMAN C, JANSE VAN VUUREN S and SUNDRUM A (2008b) Condensed laboratory methods for monitoring phytoplankton, including cyanobacteria, in South African freshwaters. WRC Report No. TT323/08. Water Research Commission, Pretoria.

VAN DER WALT M, KRÜGER M AND VAN DER WALT C (2009) The South African oxidation and disinfection manual. WISA Oxidation and Disinfection Division. WRC Report No. TT 406/09. Water Research Commission, Pretoria.

VAN GINKEL C, HOHLS BC, BELCHER A, VERMAAK E and GERBER A (2001b) Assessment of the trophic status project. Internal Report No N/0000/00/DEQ/1799. Institute for Water Quality Studies, Department of Water Affairs and Forestry, Pretoria.

VAN GINKEL C, HONGQING C, RECKNAGEL F and DU PLESSIS S (2007) Forecasting of dinoflagellate blooms in warm-monomictic hypertrophic reservoirs in South Africa by means of rule-based agents. Water SA 33 (4) 531-538.

VAN GINKEL CE; HOHLS BC AND VERMAAK E (2001a) A Ceratium hirundinella (O.F. Müller) bloom in Hartbeespoort Dam, South Africa. Water SA 27 (2) 269-276.

VENKOBACHAR C, IYENGAR L, and RAO A (1977) Mechanism of disinfection: effect of chlorine on cell membrane functions. Water Res. 11 727-729. http://dx.doi.org/10.1016/0043-1354(77)90114-2

ZAMYADI A, HO L, NEWCOMBE G, BUSTAMANTE H and PRÉVOST M (2012) Fate of toxic cyanobacterial cells and disinfection by-products after chlorination. Water Res. 46 (5) 1524-1534. http://dx.doi.org/10.1016/j.watres.2011.06.029

ZAMYADI A, HO L, NEWCOMBE G, DALY RI, BURCH M, BAKER $P$ and PRÉVOST M (2010) Release and oxidation of cell-bound saxitoxins during chlorination of Anabaena circinalis cells. Environ. Sci. Technol. 44 (23) 9055-9061. http://dx.doi.org/10.1021/ es102130b 